December 2017

\title{
Mothers and Daughters in the Digital Private Era: Review of "A Life Sentence: Victims, Offenders, Justice And My Mother" by Samantha Broun and Jay Allison and "Mariya" by Mariya Karimjee, Kaitlin Prest, and Mitra Kaboli.
}

Michele Hilmes, Professor Emerita

University of Wisconsin-Madison

Follow this and additional works at: http://ro.uow.edu.au/rdr

Part of the American Studies Commons, Audio Arts and Acoustics Commons, Digital Humanities Commons, Feminist, Gender, and Sexuality Studies Commons, and the Radio Commons

\section{Recommended Citation}

Hilmes,, Michele Professor Emerita, Mothers and Daughters in the Digital Private Era: Review of "A Life Sentence: Victims, Offenders, Justice And My Mother" by Samantha Broun and Jay Allison and "Mariya" by Mariya Karimjee, Kaitlin Prest, and Mitra Kaboli., RadioDoc Review, 3(2), 2017.

Research Online is the open access institutional repository for the University of Wollongong. For further information contact the UOW Library: research-pubs@uow.edu.au 


\title{
Mothers and Daughters in the Digital Private Era: Review of "A Life Sentence: Victims, Offenders, Justice And My Mother" by Samantha Broun and Jay Allison and "Mariya” by Mariya Karimjee, Kaitlin Prest, and Mitra Kaboli.
}

\begin{abstract}
The conditions of contemporary soundwork have sparked an extraordinary flowering of intimate storytelling, much of it told by women. Freed from the bonds of technology, scale, and forms of support and distribution that keep traditional radio relentlessly mainstream, the new "digital privacy" of the last fifteen years has allowed new kinds of stories to be told: or rather, has allowed some of the oldest stories in the world to finally be spoken aloud. In both "Mariya" and "A Life Sentence" sexual violence against women is portrayed in all its complexity, tragedy, and terrible familiarity.

In "A Life Sentence," Samantha Broun confronts the rape and brutalisation of her mother Jeremy that occurred two decades earlier, and the personal and public consequences that radiated out from it, partially through her own actions as a loving daughter. Broun's and Allison's skillful and compelling interweaving of the personal and political throughout this nearly hour-long piece makes for a hypnotically engaging experience. In "Mariya," Mariya Karimjee relates the physical and emotional consequences of the genital mutilation inflicted on her by her loving mother, also a victim of the practice, and what that means for both of them. More meditation than documentary, this story is told with a dreamlike yet matter-of-fact intensity by its author, who reads from a previously published account. Both stories plunge us into the dark complexities of power and victimisation, innocence and complicity, love and pain. Mothers and daughters: in this era of the digital private, radio 3.0, now their stories can be told.
\end{abstract}

\section{Keywords}

audio storytelling, podcasting, radio documentary, rape, female genital mutilation 


\title{
Mothers and Daughters in the Digital Private Era:
}

\author{
Review of "A Life Sentence: Victims, Offenders, Justice And My \\ Mother" by Samantha Broun and Jay Allison (Transom.org, 2016, \\ 55mins) and "Mariya" by Mariya Karimjee, Kaitlin Prest, and Mitra \\ Kaboli (The Heart, Radiotopia.fm, 2016, 35mins).
}

\author{
AUDIO links: \\ https://transom.org/2016/a-life-sentence-victims-offenders-justice-and-my-mother/ \\ https://www.thirdcoastfestival.org/explore/feature/mariya
}

\section{Reviewed by Michele Hilmes}

The conditions of contemporary soundwork have sparked an extraordinary flowering of intimate storytelling, much of it told by women. In stark contrast to "radio documentary" as we knew it before the dawn of digital sound - back when "networks" meant huge public organisations, licensed and authorised, featuring forms of expression dominated by the voices and agendas of the men who ran them - many stories were simply unspeakable, unhearable, ruled out by so many conventions of legitimate public speech as to render them nonexistent: silenced. This was particularly true of the intimate experiences of women.

History holds up a few women from the radio 1.0 era who pushed back against such conventions - creators of the reviled "soap opera" like Irna Philips who, under cover of fiction, told women-centric tales to largely female audiences; pioneers of the documentary form like Olive Shapley who battled both management and existing technology to bring the voices and concerns of working class women to the air; a few long-running discussion shows like Mary Margaret McBride's or "The Women's Hour" on the BBC that took women's interests seriously. By the late 1970s in the US, under the influence of NPR - what we might perhaps call the radio 2.0 era - a growing cadre of female producers such as the Kitchen Sisters (Davia Nelson and Nikki Silva), few of whom came from traditional radio backgrounds, began to produce a new kind of intimate, crafted, often women-centred work.

Yet even public radio could not, and still cannot, tell the stories that today's digital radio can. Freed from the bonds of technology, scale, and forms of support and distribution that keep traditiona1l radio relentlessly mainstream, the new "digital privacy" of the last fifteen years has allowed new kinds of stories to be told: or rather, has allowed some of the oldest stories in the world to finally be spoken aloud. In both "Mariya" and "A Life Sentence" sexual violence against women is portrayed in all its complexity, tragedy, and terrible familiarity. 
Indeed "family" is the keynote of both pieces, with daughters voicing the reality of their own lives with the suffering of their mothers at the centre, as both victims and, in some ways, helpless perpetrators of events that go beyond private experience into the public sphere. In "A Life Sentence," Samantha Broun confronts the rape and brutalisation of her mother Jeremy that occurred two decades earlier, and the personal and public consequences that radiated out from it, partially through her own actions as a loving daughter. In "Mariya," Mariya Karimjee relates the physical and emotional consequences of the genital mutilation inflicted on her by her loving mother, also a victim of the practice, and what that means for both of them. Both stories plunge us into the dark complexities of power and victimisation, innocence and complicity, love and pain.

Both use the first-person intimate storytelling style that has become the norm in digital radio today. "A Life Sentence" adheres to a generally journalistic format, with Broun's own narration and emotional framing intersecting with the voices of her mother, Jeremy Broun, her brother, and other significant players in a series of events culminating in a surprising set of public consequences.

Throughout, the deep emotional intimacy of this story is carried out in the way the voices of its participants are elicited and presented: we hear the tearful catches in the voices of Samantha and of her mother, Jeremy, recounting and reliving her hideous assault and nightmarish trial - at which her rapist, representing himself, interrogates her. This contrasts with the more matter-of-fact, brusque tones of her brother, who has found his own way of coping with a profound hurt, and the sympathetic yet distancing reactions of the rapist's sister, as Samantha struggles with the conflict between understanding and forgiveness.

In the story's surprising public twist, Broun recounts the path that led her to testify before a Pennsylvania Senate judiciary hearing in a successful campaign to eliminate the commutation of life prison sentences in the state; the commutation policy is what had let her mother's attacker out of jail and enabled him to assault and kill several other people in the brief period between his release and recapture. Jeremy was his only victim to survive, making her testimony crucial both to his conviction and to the public campaign. The tragic irony here is that the vast majority of those whose life sentences are commuted never commit another crime; in effect these invisible and silenced thousands of mostly minority men, locked up permanently in Pennsylvania jails, became a second set of victims, their hope taken away by the effects of a daughter's, and a community's, attempt to do good.

Another "victim" of the events is former Pennsylvania Lieutenant Governor Mark Singel, who had voted in favour of the murderer's sentence commutation. The likely winner of the 1994 gubernatorial campaign as the commutation issue became public, Singel lost in a surprising reversal to Tom Ridge, whose "law and order" campaign significantly featured Jeremy Broun's case. Singel speaks with evident emotion in his voice as Broun presses him to reflect on the greater morality of his actions, beyond his own career's ruin, contrasting with Ridge's smug politician's patter.

In the end, Broun presents us with an uplifting moment of closure focused on her mother, a former singer and actress turned addiction counsellor, whose brave directness and humanity even towards her attacker may not only have prevented her death but allowed her to survive. As a result of the brutal assault, she lost an important part of herself: her ability to sing, a deeply felt loss. Yet in the process of telling her story to her daughter, she finds her voice again both literally and figuratively as they sing together in a shaky, moving duet. Such moments are found throughout this piece, where Broun's impressive ability to 
draw out her subjects - including herself - and capture vocal emotion gives meaning far beyond what might be gained from a written narrative.

Broun's and Allison's skillful and compelling interweaving of the personal and political throughout this nearly hour-long piece makes for a hypnotically engaging experience. As she writes, "I'm acutely aware of the impact this crime has had on my mother's life, on our family's life, and I've always had a sense of its larger consequences. I thought if I could tell the story of both the intimate and the public impact, it might be worthwhile." Indeed, it is.

"Mariya" presents both complement and contrast. More meditation than documentary, this story is told with a dreamlike yet matter-of-fact intensity by its author, who reads from a previously published account. Mariya's soft-spoken vocal delivery and the narrative's acoustic detachment from any sense of place or space contrasts with startlingly frank content. The story moves with the fits and starts of a confessional rather than the smooth narrative of journalistic convention. Its producers do interesting things with pacing, using long pauses between segments enhanced by hauntingly remote music to emphasise the disconnected qualities of Mariya's quest to realise what happened to her, and why. Perhaps because of the deep intimacy and privacy of its topic, and the confessional style of its source, its composition as what we might call a vocal translation of a written source puts an extra layer of distance between the speaker and her audience: we are called to stand back and respect the storyteller's space, both culturally and personally. We suspend judgment.

This is a mystery story: Am I different from other girls? How did this happen? How could my mother do this to me, and her mother to her? What are the consequences for me in my own sexual and romantic life, and how can I even talk about it with others? As Mariya investigates the secrecy and dissimulation built up around her own memory and her own body, searching for clues in books and online forums in the face of a deeply held silence at home, she voices the same collision of intimate experience and public consequence explored by Broun. Her search, which takes her from a girlhood in Texas to college in Massachusetts and back to the Pakistan of her birth, leads only to deeper questions embedded in the mother/daughter relationship across time and cultures.

Mothers and daughters: now their stories can be told. At once unique in themselves and representative of the many truths that previous forms of radio-based soundwork have repressed, it is no wonder that these compelling docs were top winners of the Third Coast/ Richard H. Dreihaus Competition in 2016 - and no wonder that so many of the documentaries that consistently win such awards are written and produced by women in this era of the digital private, radio 3.0. 


\section{MICHELE HILMES}

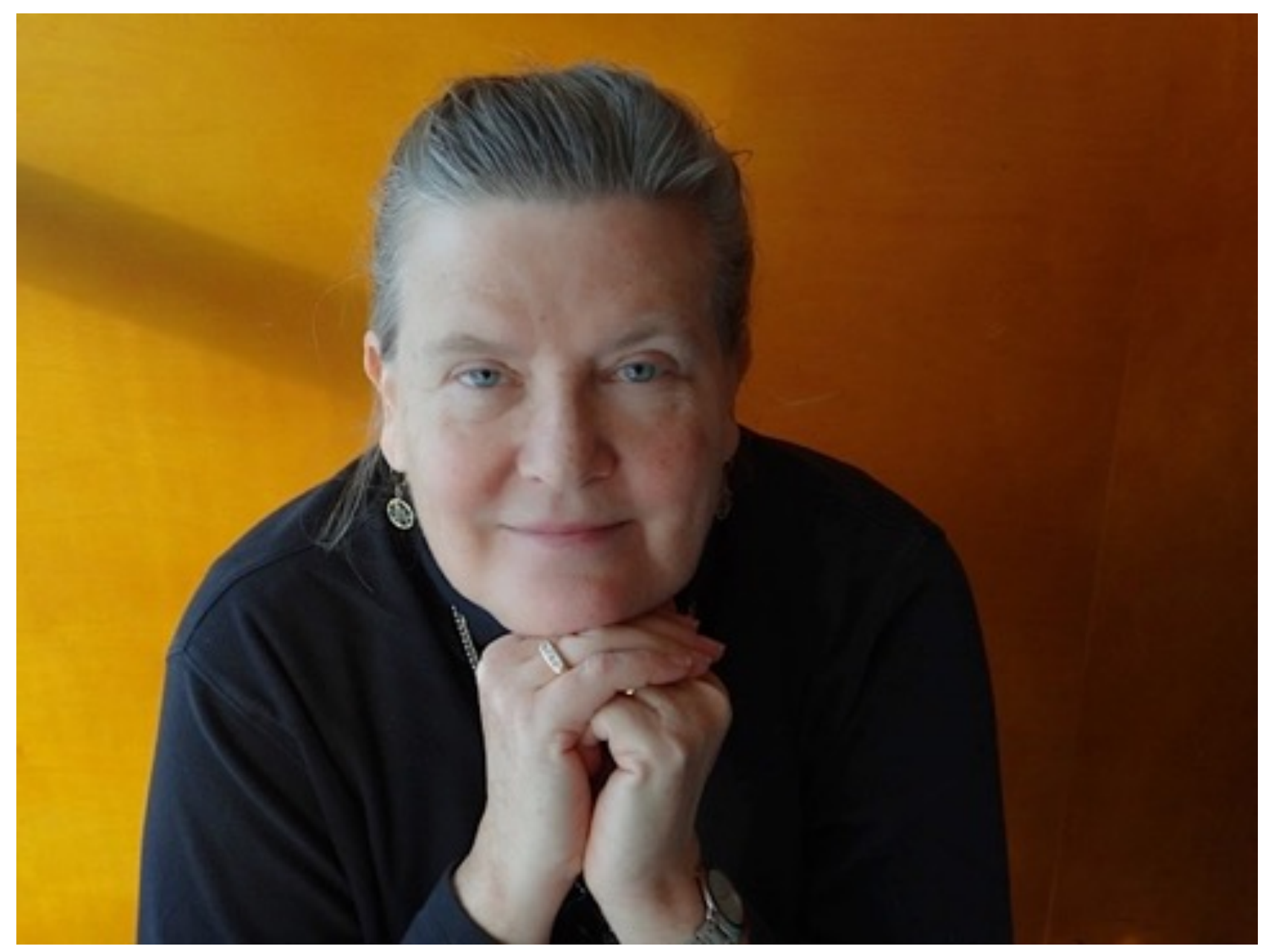

Michele Hilmes is Professor Emerita at the University of Wisconsin-Madison. Her research and publications focus on media history, with an emphasis on radio and sound studies and on transnational media flows. Her books include Radio Voices: American Broadcasting 1922-1952 (1997), Network Nations: A Transnational History of British and American Broadcasting (2011), and Only Connect: A Cultural History of Broadcasting in the United States (4 ${ }^{\text {th }}$ edition, 2013). With Dr. Mia Lindgren (Monash University), she is co-editor of The Radio Journal: International Studies in Radio and Audio Media. In 2017 she received the Distinguished Career Achievement Award from the Society for Cinema and Media Studies. 